\title{
Looking Beyond the Republic of Love or Hate in Turkey: Studies in Popular Music
}

\author{
Ali C. Gedik \\ Department of Musicology, Dokuz Eylül University \\ cenk.gedik@gmail.com

\section{Levent Ergun} \\ Department of Musicology, Dokuz Eylül University \\ levent.ergun@deu.edu.tr
}

\section{Introduction: A Brief History}

The first review of popular music studies in Turkey (Gedik 2011) was previously published in this journal. That review paved the way for two subsequent publications published in 2017. One of them was an introductory chapter of a book (Gedik 2017a), mainly reviewing the history of popular music in Turkey, and the other was mainly a critical review of popular music studies in Turkey in comparison to the Anglophone world (Gedik 2017b). These two reviews considered theoretical premises, topics, musical genres, institutions, journals, disciplinary issues, graduate theses, and advantages and disadvantages of studying popular music in Turkey in parallel to the Anglophone world, both historically and critically.

Therefore, this article will first present a summary of those reviews and then consider recent developments, again in a critical way. This new consideration will mainly focus on particular challenges, contemporary debates and emerging themes, again in parallel to the Anglophone world. The main trajectory of studies was summarized as shifts in topics and theoretical premises, as follows:

First, the shift from the sociology of arabesk in Turkey and the sociology of rock in Anglo-American popular music studies to the sociology of popular music, and, second, a parallel shift in theoretical premises from Marxism to postmodern theories. Mapping the achievements of popular music studies in Turkey, I hope to show that, despite earlier divergences from the 1990s on, Turkish popular music studies gradually converged with international practice. (Gedik 2017a: 9). 
This divergence was not just limited to the musical genre, but the distance of scholars to their subject matter was also in contrast. While scholars in the Anglophone world were fans of and in some cases even practitioners of rock music, scholars in Turkey disfavored arabesk, and were not performing it. In this sense, their positions were expressed as follows, respectively:

While rock was initially considered at IASPM conferences in relation to youth and subcultures as well as in its ideological position against mainstream popular music, in Turkey arabesk was considered in relation to lower social classes and their associated "low culture," with an ideological position favoring mainstream popular music. This comparison was one of the main themes of the arabesk debate during the 1970s and 1980s. Intellectuals who mainly belonged to the political left, ranging from social democrats to communists, considered this music as a cultural tool that leads the lower classes towards fatalism instead of political struggle. (Gedik 2017a: 10).

Although Marxism was a common theoretical premise of both branches, the kind of Marxism was another distinction. While British cultural studies was dominant in the Anglophone world, Adorno was the key figure in Turkey. Finally, studies in Turkey converged to the Anglophone world in many senses such as shift from Marxism to postmodernism:

There is also a discernible lack of critique on the destructive results of neoliberal policies, state violence, censorship, and the Islamization of society in the literature of Turkish popular music studies. Anyway, it is fair to remember that current international publications on popular music are also far from critical discourses of the formative years of popular music studies. This could be regarded as another point of convergence between studies in Turkey and the Anglo-American world. (Gedik 2017a: 14).

Thus, it could be argued that it is not a coincidence that while the definition of popular culture by Stuart Hall is one of the most cited one, its emphasis on socialism is overlooked without exception, at the same time:

It is partly where hegemony arises, and where it is secured. It is not a sphere where socialism, a socialist culture - already fully formed - might be simply 'expressed'. But it is one of the places where socialism might be constituted. That is why 'popular culture' matters. Otherwise, to tell you the truth, I don't give a damn about it. (Hall 1981: 239).

\section{Debates, Themes and Challenges}

The other publication presented a more politically-oriented approach toward the issue based on both recent political atmosphere in Turkey and the world:

An anarchist anthropologist and a leading figure in the Occupy Wall Street Movement, David Graeber (2001) expresses his disappointment about the silence of universities in the USA on neoliberalism and movements against it while they were so busy with postmodernism. According to Graeber (2001: xi), this was due to the success of postmodernism in describing the effects of neoliberalism while skipping to criticize or call for a struggle against it. (Gedik 2017b: 124). 
Grossberg (2002: 30) expressed a similar disappointment with popular music studies about its lack of critical discourses toward neoconservatism and neoliberalism. Although there was a special issue on neoliberalism and music published in Culture, Theory and Critique edited by León (2014), the interest of popular music scholars was not at its height at the date. A simple search of the term "neoliberal" within three of the leading journals on popular music in the Anglophone world showed that only 109 articles out of 3519 articles involved the term (Gedik 2017b: 125).

It is clearer today that the crisis of capitalism and its political and ideological program, neoliberalism, have led to more totalitarian regimes, globally, more than ever. For example, recent political performances of leading politicians in Turkey and the USA either on international or domestic issues demonstrate a terrifying level of totalitarianism. No doubt, despite the universality of neoliberalism, it has certain peculiarities in Turkey, naturally. For example, the overlap of neoliberal policies and the military coup in Turkey in 1980 was not surprising. The result of this overlap was destruction of left-wing and working-class movements and the sale of public assets and privatization of public services. A Turkish-Islamic synthesis involving neo-Ottomanism accompanied this process as the new official ideology with specific variations to date.

The most extreme period of this process was the last two decades, governed by The Justice and Development Party (Adalet ve Kalkınma Partisi, AKP), an Islamic neoliberal political party:

This was (...) a long process consisting of neoliberal transformations and Islamization of society. In short, this policy was called the Neo-Ottomanism and promoted against past official ideology of the Republic, especially towards its nationalism, westernization, secularism and peaceful policies in international relations. (Gedik 2017b: 120).

Until recently, AKP achieved the preservation of its hegemony, supported by a historical bloc in the Gramscian sense, that consisted of capitalist class, religious communities, both right-wing and left-wing liberal intellectuals and even the Kurdish political movement and various socialist parties supporting it. Simply, AKP was the symbol of a great success of the liberal (Islamic) periphery against an authoritarian (secular) center for this bloc. The beginning of the end of this hegemony was started most clearly by the Gezi Park resistance in 2013 and reached its low point by the loss at local elections in many cities in 2019. Yet, its hegemony has not disappeared entirely.

As a result, those reviews were criticizing popular music studies in Turkey, following Grossberg (2002), due to their indifference to these processes in terms of musical practices either as a victim or a supporter of, or as somebody struggling against them. In this sense, those reviews could also be considered as a contemporary debate on the issue, despite the fact that there has not been any published response so far. On the contrary, a specific theme, the critique of past republican musical policies, became dominant, recently.

One of the few music sociologists in Turkey, Güneş Ayas has been most productive for such criticisms. His first monograph, Sociology of Musical Revolution (Ayas 2014) is completely dedicated to this issue. His next book, Sociology of Music (Ayas 2015) which is a unique contribution in Turkish, also includes five chapters dedicated to critique past republican musical policies. An important part of his recent book, Noise Muting Music (Ayas 2018), again, consists of articles criticizing the same issue. 
In fact, this theme had already been studied by various leading scholars. Tekelioğlu (1996, 2001, 2006), Balkılıç (2009) Erol (2012) and Yıldız (2013) all considered the issue from different points of view. In this sense, it should be noted that critique of past republican policies has never been peculiar to Islamist political thought, completely. On the contrary, both liberalism and socialism in Turkey have their distinct but also sometimes overlapping critical approaches toward republican policies. Therefore, this line of critique continued by Ayas has never been positioned against the republican past, as Islamists. Yet, this line of critique usually considered the issue as an example of westernization, modernization and nationstate building processes which could be observed in many parts of the world.

Nevertheless, it should be noted that Ayas (2014) has a certain emotional bias confessed in his preface - toward the issue, since he is a performer of traditional Ottoman/Turkish art music which was a victim of the early republican policies. In this sense, contributions of Signel (1977), O'Connell (2000, 2005, 2016), Gill $(2011,2017,2018)$ and Greve $(2018)$ on the issue seem to succeed in preserving a certain distance of a scholar toward the research subject, which could be considered as an advantage of outsiders, even though some of them became qualified performers of this musical tradition.

A recent book edited by Kutluk (2016a) and contributed by some leading scholars seemed to blur this line of critique. As the title of the book reveals, I/lusion: Classical Music Adventure of Republic, all the republican past, not only its musical policies are considered as an illusion and criticized, very harshly, more than ever before. Especially, the last two chapters by Güray (2016) and Çevikoğlu (2016) make the book go beyond a timid support of government policies. Both authors clearly express their satisfaction with the current musical policies compared to the past republican ones.

The next book on the same topic, titled Musical Policies of the Republic, was again edited by Kutluk (2018) and included chapters from the same four authors of the previous book. The main theme was the same as the previous book, (critique of republican musical policies) but this time the level of critique was more moderate with few exceptions. Even Güray (2018) seemed to switch to a timid critique of policies of the government. Furthermore, new authors of this book, Satır and Reyhan (2018) gave place to a critique of neoliberalism, Islamism and neo-Ottomanism of the government. Especially, the interview with the foremost performers of European art music in Turkey by the editor is quite in contrast with both books. Their critiques of republican musical policies were also acknowledging the achievements of the republic. Therefore, this topic could be considered as a particular challenge facing popular music studies in Turkey on the issue.

Islamic pop is another emerging theme regarded either as transformation of a protest music toward commercialization after the AKP's accession to power, as another musical practice suppressed by republican policies previously (Taş 2014; Yenen 2016), or as a musical practice supporting new official ideology (Özdemir 2017), or as an appearance of a glocal musical phenomena in Turkey (Erol 2017). A recent book by Erol (2018), Islam, Alevism and Music also presents a collection of extended and revised articles previously published in English. This book represents a unique source in Turkish with its comprehensive approach on religious musical practices related to Islam. It also contains a chapter on Alevi semah, which is related with another emerging and heretofore neglected topic, dance.

Although recent studies mainly focus on traditional dance practices, they are distinct from the past studies by their disciplinary approaches other than folklore, such as sociology, history, popular music studies and ethnomusicology. In this 
sense, studies of Markoff (1993), Öztürkmen (1995, 2005), Erol (2010), Tambar (2010) and Özdemir (2016) all focused on the Alevi semah. In a similar fashion, a recent book edited by Özbilgin and Mellish (2018) discusses folk dance festivals, and the study of Vicente (2019) considers whirling dervish shows within the context of tourism in Egypt and Turkey.

One of the oldest journals on music in Turkey, Porte Akademik: Journal of Music and Dance Studies which gives place to popular music studies, as well, published a special issue on dance in 2011. Similarly, two chapters of an edited book by Öztürkmen (2013), Music, Dance, Performance, are dedicated to historical and theoretical approaches to dance studies in general without focusing on any specific dance practice. Finally, two recent monographies by Öztürkmen (2016) and Kurt (2017) again criticize early republican policies by focusing on dance practices. It seems surprising that there is still no publication on either one of the hottest topics in popular music studies, electronic dance music or other dance practices related to popular music.

The monograph of Girgin (2015) diverges from these studies not only by considering another traditional dance practice, Roman dance, but also by discussing a dance practice of a minority group without criticizing early republican policies. Since early republican policies were based on a political project of building a nation-state, minorities and their musical practices were natural victims of assimilation, in various degrees. In this sense, studies on the musical practices of minorities such as Kurdish, Armenian, Greek, Laz, and Romany all focus on the critique of republican policies. Yarar (2017) presents a comprehensive review of these studies within the context of multiculturalism which was also kept as a part of neo-Ottomanism policies by AKP, for a long time.

Nevertheless, there are few studies on musical practices of minorities within the context of global process without an emphasis on the critique of republican policies such as the ones by Aksoy $(2006,2013,2017)$ and Gönenç et al. (2014) on Kurdish music and Girgin (2018) on Roman music. The studies of Gönenç et al. (2014) and Girgin (2018) also diverge in the sense that the former considers Kurdish music and dance as a culture of political acts of Kurdish people and the latter discusses the Roman/Gypsy music within the context of world music by criticizing their relation with neoliberalism, post-Fordism and creative industries. Therefore, Girgin (2018) discusses one of the neglected themes in popular music studies in Turkey, the political economy of popular music. Few studies on another minority group, Laz, also consider the issue on a similar basis (Stokes 1993; Kolivar 2011; Solomon 2017). Finally, the studies of Schäfers (2019) and, Greve and Şahin (2019) on Kurdish music could be considered as of taking a similar line of approach. Aksoy (2019) considers another minority group, the Alevi, in Turkey but within the context of their migration to Germany.

Recently, two articles considering Anadolu Pop include critiques of early republican musical policies, again in varying degrees. Although these two articles have different theoretical premises within different historical contexts, both articles discuss the link between the early republican musical policies and Anadolu Pop. In this sense, while Ergun (2017) focuses on the effect of official ideology on the emergence of the genre, Baysal (2018) completely dedicates his study to revealing the link between the early republican musical policies and Anadolu Pop.

Ergun's study (2017) mainly focuses on The Golden Microphone Contest held by a mainstream newspaper, Hürriyet Daily News, which is an important published media of official ideology. He discusses Golden Microphone as an important series of contests for the emergence of the genre from a Marxist point of view of British 
Cultural Studies and thus considers this process not only as a site for supporting official ideology but also resisting it. On the contrary, Baysal (2018) mainly reduces Anadolu Pop as a musical genre to an ideological apparatus completely in line with early republican musical policies and thus official ideology. Therefore, one of the revolutionary periods of Turkey in terms of left-wing and working-class movements against the capitalist state and its official ideology and one of their foremost musical expression, Anadolu Pop, seems to be overlooked completely by Baysal (2018).

It is interesting enough that most of the studies are unconcerned with the neoliberal transformation and Islamization processes, for example, massacres such as the one in Sivas in 1993 by extreme Islamist militants toward mostly Alevi intellectuals including musicians or arrested and jailed oppositional musicians by right-wing governments. However, considering this fact together with an indifference to musical practices in response to these processes, for example, highly intense appearances of live musical practices during the Gezi Park resistance, requires a further explanation.

Earlier, an attempt for such an explanation was considered as twofold: political and theoretical (Gedik 2017b). The political side was expressed with reference to Stokes (2010: 9) who called it a cliché: "Modern Turkey has routinely been understood as a secular modernizing state imposing reforms on a 'traditional' and Islamic periphery". And this cliché was applied to more recent government policies as follow:

Besides neoliberal transformations and Islamization, the policies of AKP included the goal of being a member of the EU and downplaying the role of the military forces, which acted as a real political party in power, even in democratic periods. Therefore, these policies were appreciated as a democratization process by a wide range of political actors from some extreme left to whole liberal right. (Gedik 2017b).

This political side is based on a theoretical premise which Marxist scholar Wood (2002: 33) called a bourgeois paradigm, presupposing direct conflict between the aristocracy and the bourgeoisie for the emergence of capitalism. Therefore, the history of Turkey is regarded as a struggle between center and periphery, instead of a class struggle in a capitalist social formation:

[Turkey] is considered either as abnormal capitalist formation as a consequence of a bourgeois revolution without a bourgeois class, or as a social formation where capitalism is not the dominant mode of production due to a lack of a real bourgeois revolution. (Gedik 2017c)

In fact, even leading labor historians studying Ottoman Empire demonstrated how the empire was articulated by mean of capitalist relations of production via Europe and thus was subject to capitalist class struggles, as well. As a result, popular music studies in Turkey could also be explained by the strength of the hegemony supported by a historical bloc which produced consent over a wide range of political actors for a long period of time. However, it could be also explained by almost sheer coercion after the disintegration of the historical bloc. The rather recent coercion resulted with firing of hundreds of mostly leftist scholars from universities whom signed a peace declaration against violent solutions to the Kurdish question.

In this sense, few studies by colleagues from abroad discuss some topics mostly neglected by Turkish scholars. The studies of Mehrabov (2013) and Bates (2014) 
focus on distribution and production of protest music. Mehrabov (2013) considers one of the foremost new protest music groups, Bandista and its alternative music distribution strategies, such as copyleft. Bates (2014) reveals the music production process of the oldest and leading protest music group, Grup Yorum, whose members are still under arrest and in hunger strike for months, in terms of distributed recording production. Similarly, Bianchi (2018) and Parkinson (2018) look at the musical practices of the Gezi Park resistance from different points of view. Bianchi (2018) focuses on the role of music in 'Gezi Park Occupy movement' and Parkinson (2018) discusses counter-hegemonic music related to Gezi Park protests.

In fact, a violent event on 17 June 2016 in Istanbul cited by Parkinson (2018: 59) in its conclusion summarizes the destructive results of Islamization which I tried to point out, so far:

(...) a launch party for the band Radiohead's album A Moon-shaped Pool at Velvet IndieGround, a small independent record store in the Çukurcuma neighbourhood of Beyoğlu, was attacked by a gang of 25 men wielding metal bars. The attack received global media attention. The public consumption of alcohol during ramazan appears to have been the gang's principal grievance, but the altercation speaks more broadly to the ideological fault lines in Turkish society (...)

Although the study by Otterbeck et al. (2018) is not about protest music, he discusses black metal in Turkey and Saudi Arabia as a subcultural strong protest against the Islamic ideology of the government. Finally, Way (2017) presents a comprehensive approach to popular music in Turkey by especially focusing on the fifteen years of the AKP government. Way's monograph applies multimodal critical discourse analysis for discussing popular music in relation to ideology, control and resistance in those years.

\section{Recent Achievements}

Various themes or theoretical approaches that either have been neglected or received little attention so far also appeared in recent publications. The monograph by Ersoy Çak and Beşiroğlu (2017) is outstanding in the sense that a postmodernist approach is applied to the issue of gender for the case of Zeki Müren, a controversial icon in the history of popular music in Turkey. Another book by Kutluk (2016b) considers issues of gender in Western art music and presents a survey of interviews based on the question of the masculinity in rock music. Galioğlu (2016) also contributes to the book with a chapter on dance and sexuality based on her research on Latin dance courses. Finally, Uyar and Karahasanoğlu (2016) present early performances of jazz music in Turkey. Meanwhile, another neglected topic, the ethnomusicology of music production is continued to be studied by Bates (2016), one of the leading names of this rather new research area, who focuses on recording studios in Istanbul.

It is important to note that one of the criticisms of popular music studies in the Anglophone world, namely, the lack of ethnography Bates 2013), seems to be less valid for studies in Turkey. No doubt, in order to make such comparison a statistical analysis is necessary. However, it could be easily argued that most of the studies reviewed so far both in this article and in the other three past reviews, are based on ethnographic research. The roles of ethnomusicologists from abroad such as O'Connell, Stokes, Solomon and Bates, and native ethnomusicologist Erol are 
indisputable for this achievement. Both fieldwork of those guest ethnomusicologists in Turkey and especially publications of Martin Stokes' research in Turkish legitimize the study of popular music and ethnography. Furthermore, Erol is not only the author of sources on popular music studies which became regular textbooks in many music departments, but he is also a leading figure with his fieldworks both in Turkey and abroad such as Canada and Finland, and for the foundation of Turkey Branch of IASPM in 1999.

Although there is not a fruitful relation between popular music scholars and popular music critics in Turkey as in the Anglophone world, it is evident that critics have also published important voluminous books which scholars also benefit from. Recently, three books by Bengi $(2016,2017,2018)$ present the 1950s, 1960s and 1970 s of Turkey in each volume by considering the popular musics of each period in an encyclopedic fashion. Similarly, the study of Beşer (2016) represents a unique contribution to the issue by considering rather isolated and unknown musical personalities such as LP shop salesmen, mobile cassette sellers, shoeshine boys, amateur musicians and music journal publishers and writers who all contributed to popular music somehow.

The lack of conferences or symposiums on popular music in Turkey has been compensated so far by musical conferences or symposiums on different issues which are all open to contributions on popular music. Similarly, two journals, Etnomüzikoloji Dergisi ("Ethnomusicology Journal") and Musicologist, which started publication in 2017 have been quite open to popular music studies. In this sense, both the foundation of Etnomüzikoloji Derneği ("Association of Ethnomusicology") in 2017, and its first symposium held in 2018 seems to contribute to the study of popular music in Turkey.

International Encyclopedia entries on Turkish popular music by native scholars could be considered another achievement of studies in Turkey, which were once written by scholars from abroad. In this sense, contributions of Kurtişoğlu and Öztürkmen (2018) on halay, a traditional dance, and Kurtişoğlu (2019) on Turkey regarding its music in relation to history, culture, and geography, and contributions of Erol $(2016,2019)$ on a key figure of arabesk, Müslüm Gürses, and arabesk, respectively, published in Encyclopaedia of Islam and The Sage Encyclopedia of Music and Culture could be listed.

Yılmaz's book (2017), published in Turkish and dedicated to discussions on popular music in Turkey as well as an international book titled Made in Turkey: Studies on Popular Music by Gedik (2017), are other recent developments. Made in Turkey is dedicated completely to Turkish popular music and comprises of chapters written by native scholars, except for an afterword by Martin Stokes. This book was a result of a Global Popular Music Studies project by leading scholars Plastino and Fabbri. As series editors, they insisted on the contribution of native scholars for each volume dedicated to popular music of their country or region.

Finally, it is necessary to highlight that this critical consideration is not about the existing studies themselves exclusively but about the non-existing ones. Therefore, we mainly tried to discuss why certain critical studies are lacking, rather than the plurality of the existing ones. In other words, our main argument is that the lack of such studies is diminishing the plurality of popular music studies both in Turkey and the Anglophone world:

No doubt, neither any critical discourses nor any theoretical premises would guarantee better studies. In this sense I believe that popular music studies both in Turkey and the Anglophone world have an impressive state-of-art with its every kind of plurality. Therefore, I think such a plurality with applying critical 
discourses as once done by pioneering names of our community would likely contribute to a more just and equal world. (Gedik 2017b).

\section{References}

Aksoy, O. E. -

2006. The Politicization of Kurdish Folk Songs in Turkey in the 1990s. Music and Anthropology 11. http://www.umbc.edu/MA/index/maind.htm. Accessed 8 October 2017.

2013. Music and Reconciliation in Turkey. In C. Gunes and W. Zeydanlioglu Eds. The Kurdish Question in Turkey. New York: Routledge: 241-260.

2017. Kurdish Popular Music in Turkey. In A. C. Gedik Ed. Made in Turkey. Studies in Popular Music. New York: Routledge: 149-166.

2019. Music and Migration Among the Alevi Immigrants from Turkey in Germany. Ethnic and Racial Studies 42 (6): 919-936.

Ayas, G. -

2014. Musiki inkılabının Sosyolojisi: Klasik Türk Müziğ i Geleneğ inde Süreklilik ve Değ işim. Istanbul: Doğu Kitabevi.

2015. Müzik Sosyolojisi. Istanbul: Doğu Kitabevi.

2018. Müziği Boğan Günü/tü: ideolojinin Kıskacındaki 'Musiki'. İstanbul: İthaki Yayınları.

Balkılıç, Ö. 2009. Cumhuriyet, Halk ve Müzik: Türkiye'de Müzik Reformu 19221952. Ankara: Tan Kitabevi Yayınları.

Bates, E. -

2013. Popular Music Studies and the Problems of Sound, Society and Method. Journal of the International Association for the Study of Popular Music 3 (2): 15-32.

2014. Music, Mobility and Distributed Recording Production in Turkish Protest Music. In J. Stanyek and S. Gopinath Eds. Oxford Handbook of Mobile Music Studies, Volume 2. New York: Oxford University: 339-60.

2016. Digital Tradition: Arrangement and Labor in Istanbul's Recording Studio Culture. New York: Oxford University Press.

Baysal, O. 2018. Reconsidering "Anadolu Pop". Rock Music Studies 5 (3): 205219.

Bengi, D. -

2016. 50'li Yıllarda Türkiye: Sazlı Cazlı Sözlük- 'Şimdiki Zaman Beledir'. İstanbul: Yapı Kredi Yayınları.

2017. 60'lı Yıllarda Türkiye: Sazlı Cazlı Sözlük 'Dünya Durmadan Dönüyor'. İstanbul: Yapı Kredi Yayınları.

2018. TO'li Yıllarda Türkiye: Sazlı Cazlı Sözlük 'Görecek Günler Var Daha'. İstanbul: Yapı Kredi Yayınları.

Beşer, M. 2016. Yoldan Çıkmış Simalar. İstanbul: illetişim Yayıncılık.

Bianchi, R. 2018. Istanbul Sounding Like Revolution: The Role of Music in the Gezi Park Occupy Movement. Popular Music 37 (2): 212-236.

Çevikoğlu, T. 2016. Devlet Türk Müziği Koroları. In F. Kutluk Ed. i/lüzyon:

Cumhuriyet'in Klasik Müzik Senü veni. Istanbul: H2O Yayıncılık: 257-274.

Ergun, L. 2017. The Golden Microphone as a Moment of Hegemony. In A. C.

Gedik Ed. Made in Turkey. Studies in Popular Music. New York: Routledge:

75-88. 
Erol, A. -

2010. Re-imagining Identity: The Transformation of the Alevi Semah. Middle Eastern Studies, 46 (3): 375-387

2012. Music, Power and Symbolic Violence: The Turkish State's Music Policies during the Early Republican Period. European Journal of Culture Studies 15: 35-52.

2016. Müslüm Gürses. In K. Fleet, G. Krämer, D. Matringe, J. Nawas and E. Rowson Eds. Encyclopaedia of Islam Three. Leiden: Brill. http://dx.doi.org/10.1163/1573-3912_ei3_COM_30135

2017. The Glocality of Islamic Popular Music: The Turkish Case. In A. C. Gedik Ed. Made in Turkey: Studies in Popular Music. New York: Routledge: 107118.

2018. Islam, Alevilik ve Müzik. İstanbul: Bağlam Yayınları.

2019. Arabesk. In J. Sturman Ed. The Sage International Encyclopedia of Music and Culture, Volume 1. Thousand Oaks, CA: Sage: 163-166.

Ersoy Çak, Ş. and Beşiroğlu, Ş. Ş. 2017. Bir Muhabbet Kuşu: Postmodern

Göstergeler Işığında Zeki Müren. İstanbul: Tarih Vakfı Yurt Yayınları.

Galioğlu, A. 2016. Dans ve Cinsellik. In F. Kutluk Ed. Müzikte Cinsellik. İstanbul:

H2O Yayıncılık: 75-107.

Gedik, A. C. -

2011. Reflections on Popular Music Studies in Turkey. IASPM Journa/2(1-2): 51 56.

2017a. Introduction: Struggling with and Discussing a "Republic" through Popular Music. In A. C. Gedik Ed. Made in Turkey: Studies in Popular Music. New York: Routledge: 1-19.

2017b. Mapping Popular Music Studies in Turkey Onto Studies in the Anglophone World. In J. Merrill Ed. Popular Music Studies Today. Wiesbaden: Springer VS: 119-128.

2017c. Class Struggle in Popular Musics of Turkey: Changing Sounds from the Left. In A. C. Gedik Ed. Made in Turkey: Studies in Popular Music. New York: Routledge: 89-106.

Gill-Gürtan, D. 2011. Performing Meşk, Narrating History: Legacies of

Transmission in Contemporary Turkish Musical Practices. Comparative Studies of South Asia, Africa and the Middle East 31 (3): 615-630.

Gill, D. -

2017. Melancholic Modalities: Affect, Islam, and Turkish Classical Musicians. Oxford: Oxford University Press.

2018. Listening, Muhabbet, and the Practice of Masculinity. Ethnomusicology 62 (2): 171-205.

Girgin, G. -

2015. 9/8 Roman Dansı: Kültür, Kimlik, Dönüşüm ve Yeniden inşa. İstanbul: Kolektif Kitap.

2018, Dünya Çingeneleri Konuşuyor Post-fordizm, Yaratıcı Endüstriler ve Dünya Müziği. MSGSÜ Sosyal Bilimler Dergisi 2 (18): 349-358.

Gönenç, H., Beşiroğlu, ş. ş. and Reigle, R. 2014. Müzik, Dans ve Türkiye'de Kürtlerin Politik Eylem Kültürü. Porte Akademik: Müzik ve Dans Araştrrmalan Dergisi 10: 158-166.

Graeber, D. 2001. Toward an Anthropological Theory of Value: The False Coin of Our Own Dreams. New York: Palgrave.

Greve, M. 2018. Makamsız: Individualization of Taditional Music on the Eve of Kemalist Turkey. Würzburg: Ergon Verlag. 
Greve, M. and Şahin, Ö. 2019. Anlatlamazı Ifade Etmek: Yeni Dersim Soundunun Oluşumu. İstanbul: Tarih Vakfı Yurt Yayınları.

Grossberg, L. 2002. Reflections of a Disappointed Popular Music Scholar. In R. Beebee, D. Fulbrook \& B. Saunders Eds. Rock Over the Edge: Transformations in Popular Music Culture. London: Duke University Press: 25-59.

Güray, C. -

2016. Cumhuriyetin ilk Yıllarından Günümüze Hükümet Programlarında Müzik:

Eleştirel Bir Bakış. In F. Kutluk Ed. I/lüzyon: Cumhuriyet'in Klasik Müzik

Senü veni. Istanbul: H2O Yayıncılık: 231-256.

2018. Cumhuriyet Politikalarının Halk Müziğine Yaklaşımı: Bir Toplumsal

Dönüşüm Modeli. In F. Kutluk Ed. Cumhuriyet'in Müzik Politikalan. İstanbul: H2O Yayıncılık: 15-45.

Kolivar, A. 2011. Kentli bir Yerel Kimlik Temsili Olarak Karadeniz Rock. Porte Akademik: Müzik ve Dans Araştırmalan Dergisi 1 (2): 76-85.

Kurt, B. 2017. 'Ulus'un Dansı ': Türk Halk Oyunlan Geleneğ inin icadı. İstanbul: Pan Yayıncılık.

Kurtişoğlu, B. and Öztürkmen, A. 2018. Halay. In K. Fleet, G. Krämer, D. Matringe, J. Nawas and E. Rowson Eds. Encyclopaedia of Islam Three. Leiden: Brill. http://dx.doi.org/10.1163/1573-3912_ei3_COM_30223

Kurtişoğlu, B. 2019. Turkey: Music in History, Culture, and Geography. In J. Sturman Ed. The Sage International Encyclopedia of Music and Culture, Volume 1. Thousand Oaks, CA: Sage. http://dx.doi.org/10.1163/1573-3912_ei3_COM_30223

Kutluk, F., Ed. 2016a. I/lüzyon: Cumhuriyet'in Klasik Müzik Senü veni. İstanbul: H2O

Yayıncılık. 2018. Cumhuriyet'in Müzik Politikalan. İstanbul: H2O Yayıncılık.

Kutluk, F., 2016b. Müzikte Cinsellik. İstanbul: H2O Yayıncılık.

Markoff, I. 1993. Music, Saints and Ritual: Sama' and the Alevis of Turkey. In G. M. Smith and C. W. Ernst Eds. Manifestations of Sainthood in Islam. Istanbul: Isis: 95-110.

Mehrabov, I. 2013. Turkey and the Copyleft Music Production: Reflections on Bandista. IASPM Journal 3 (1): 80-90.

O'Connell, J. M. 2000. Fine Art, Fine Music: Controlling Turkish Taste at the Fine Arts Academy in 1926. Yearbook for Traditional Music 32: 117-142.

2005. In the Time of Alaturka: Identifying Difference in Musical Discourse. Ethnomusicology 49 (2): 177-205. 2016. Alaturka: Style in Turkish Music (1923-1938). Routledge.

Otterbeck, J., Mattsson, D., and Pastene, O. 2018. "I am Satan!" Black Metal, Islam and Blasphemy in Turkey and Saudi Arabia. Contemporary Islam 12 (3): 267-286.

Özbilgin M. Ö. and Mellish, L., Eds. 2018. The Cultural Development of Folk Dance Festivals and the Sustainability of Tradition. Izmir: Ege University Press.

Özdemir, Ö. 2017. Rap'in Krallarından Geçtim Gönül Sultanlarına Bağlandım: Türkiye'de Islami ve Tasavvufi Rap Müzik. Kü/tür ve Iletiş̧im 20 (39): 229-248.

Özdemir, U. 2016. Kimlik, Rituel, Müzik icrası: Istanbul Cemevlerinde Zakirlik Hizmeti. Istanbul: Kolektif Kitap.

Öztürkmen, A. - 
1995. The Alevi Cem Ritual and the Nationalization of Semah Dances. In G. Dabrowska and L. Bielawski Eds. Dance, Ritual, and Music. Warsaw: Polish Academy of Sciences: 127-132.

2005. Staging a Ritual Dance out of its Context: The Role of an Individual Artist in Transforming the Alevi Semah. Asian Folklore Studies 64 (2): 247-260.

2016. Rakstan Oyuna: Türkiye'de Dansın Modern Halleri. Istanbul: Boğaziçi Üniversitesi Yayınevi.

Öztürkmen, A., Ed. 2013. Müzik, Dans, Gösterim: Tarihse/ ve Kuramsal Tartş̧malar. Istanbul: Boğaziçi Üniversitesi Yayınevi.

Parkinson, T. 2018. 'Indiestanbul': Counter-Hegemonic Music and Third Republicanism in Turkey. Popular Music 37 (1): 40-62.

Satır, Ö.C. and Reyhan, H. 2018. Yürü Türk Oğlu! Bir Cumhuriyet İdeolojisi olarak Türk Kimliğinin İnşasında Marşlar ve Çocuk Şarkıları. In F. Kutluk Ed. Cumhuriyet'in Müzik Politikalan. İstanbul: H2O Yayıncılık: 203-230.

Schäfers, M. 2019. Archived Voices, Acoustic Traces, and the Reverberations of Kurdish History in Modern Turkey. Comparative Studies in Society and History 61 (2): 447-473.

Signel, K. L. 1977. Makam: Modal Practice in Turkish Art Music. Seattle: Asian Music Publications.

Solomon, T. 2017. Who Are the Laz? Cultural Identity and the Musical Public Sphere on the Turkish Black Sea Coast. World of Music 6 (2): 83-113.

Stokes, M.

1993 Hazelnuts and Lutes: Perceptions of Change in a Black Sea Valley. In P. Stirling Ed. Culture and Economy: Changes in Turkish Villages. Huntingdon: The Eothen Press: 21-45.

2010. The Republic of Love: Cultural Intimacy in Turkish Popular Music. London: The University of Chicago Press.

Tambar, K. 2010. The Aesthetics of Public Visibility: Alevi Semah and the Paradoxes of Pluralism in Turkey. Comparative Studies in Society and History. 52 (3): 652-679.

Taş, H. 2014. Melodies of Resistance: Islamic Music in Secular Turkey. Social Compass 61 (3): 368-383.

Tekelioğlu, O. -

1996. The Rise of a Spontaneous Synthesis: Historical Background of Turkish Popular Music. Middle Eastern Studies 32 (1): 194-216.

2001. An Inner History of "Turkish Music Revolution": Demise of a Music Magazine. In Sufism, Music and Society in Turkey and the Middle East London: Curzon Press: 111-124.

2006. Pop Yazılar: Varoşlardan Merkeze Yürüyen "Halk Zevki". İstanbul: Telos Yay.

Uyar, Y. M. and Karahasanoğlu, S. 2016. The Early Performance of Jazz Music in Turkey. Porte Akademik: Müzik ve Dans Araşttrmalan Dergisi 13: 129-139.

Vicente, V. A. 2019. Itineraries of Enlightenment: Whirling Dervish Shows, Ethnographic Reflexivity, and Tourism in Egypt and Turkey. Musicologist 3 (1): $37-57$.

Way, L. C. 2017. Popular Music and Multimodal Critical Discourse Studies: Ideology, Control and Resistance in Turkey Since 2002. London: Bloomsbury Publishing.

Wood, E.M. 2002. The Origins of Capitalism: A Longer View. London: Verso. 
Yarar, B. (2017). Arabesk: Looking at the History of Popular Meanings and Feelings in Turkey. In A. C. Gedik Ed. Made in Turkey: Studies in Popular Music. New York: Routledge: 179-192.

Yenen, ì. 2016. Din, Müzik ve Kimlik Bağlamında Türkiye'de İslami Popüler Müzik. Tarih Kültür ve Sanat Araştırmalan Dergisi 5 (2): 1-25.

Yıldız, B. 2013. Music Politics in the Process of Founding Turkish Nationalism. Scottish Journal of Arts, Social Sciences and Scientific Studies 11: 3-11.

Yımaz, Ö. 2017. Türkiye'de Popüler Müzik Tartş̧malan. İstanbul: Bilim ve Gelecek Yay. 